\title{
Çalışma Yaşamı Kalitesinin İş Memnuniyeti ve Bağlılık Üzerine Etkileri: Seyahat Acentaları Üzerine Bir Araştırma
}

\author{
Doç. Dr. Oğuz TÜRKAY \\ Sakarya Üniversitesi, İsletme Fakültesi, Turizm İşletmeciliği Bölümü, SAKARYA
}

\begin{abstract}
ÖZET-
Çalışma yaşamı kalitesi bir çalışanın işyeri ile ilgili farklı konulardaki algılamasını ortaya koymaktadır. İsyeri ile ilgili bu algılamaların, çalışanın işinden memnun olma, çalıştı̆̆ işletmede uzun yıllar çalı̧̧ma arzusu ve ilgili iş kolunda uzun yillar çalışma arzusu üzerinde etkileri olacaktır. $\mathrm{Bu}$ çalışmada, çalışma yaşamı kalitesini belirleyen değişkenlerden hangilerinin iş memnuniyeti, işletmeye bağlllık ve işkoluna bağlllık üzerinde anlamlı etkileri olduğunun ortaya konulması amaçlanmıştır. Seyahat acentası çalışanlarından anket tekniği kullanılarak elde edilen veriler sıralı regresyon tekniği ile analiz edilmiştir. Çalışma yaşamiyla ilgili olarak algılanan ve iş memnuniyeti, işletmeye bağlllık ve işkoluna bağglllı olgularını açılklama gücü olan etkenler tespit edilmiştir.
\end{abstract}

Anahtar Kelimeler: Çalışma yaşamı kalitesi; iş doyumu; işletmeye bağlılık; işkoluna bağlllık; siralı regresyon testi; seyahat acentaları.

JEL Sinıflaması: J81, M12, M54

\section{Effects of the Quality of Work Life on Job Satisfaction and Commitment: a Research on Travel Agencies}

\begin{abstract}
The quality of work life reveals how an employee perceives different aspects of his/ her workplace. Such perceptions with respect to the workplace have effects on job satisfaction, the desire to work in the current organization and the desire to work in the relevant line of work for years to come. The objective of the present study is to determine which determinants of the quality of work life have significant effects on job satisfaction, commitment to the organization and line of work. Data derived from employees of travel agencies by using the questionnaire technique was analyzed by using ordinal regression technique. The factors that affect job satisfaction, commitment to organization and commitment to line of work were detected.
\end{abstract}

Key Words: Quality of work life; job satisfaction; commitment to organization; commitment to line of work; ordinal regression; travel agencies

JEL Classification: J81, M12, M54

\section{GİRIŞ}

İnsanlar için iş ne kadar önemliyse, iş ve işyeriyle ilgili algılamaları da o oranda önemlidir. İş ve iş ortamı insan hayatında belirleyici etkiler ortaya koymaktadır. Çoğu insan, çalıştığı işe sadece para kazanma açısından bakmaz. O işi yapıyor olmanın verdiği bir tatmini, gururu, başarı hissini, işi aracılığıyla milli ekonomiye ve topluma katkı sunma duygusunu da yaşamaktadır. İşinden memnun olmama durumunda ise tam tersine bir stres ve hoşnutsuzluğun hâkim olduğu ruhsal bir iklimi yaşamak durumunda kalmaktadır. Bu bakımdan, çalışan bireyin hayatında çok önemli, köklü ve doldurulamaz bir yeri vardır. Bu önemine paralel 
olarak bireyin hayatında olumlu rol oynaması mevcut iş yaşamının kalitesine bağlıdır. Çalışma yaşamı kalitesi (ÇYK) kişinin işinden, işyerinden ve mesleğinden beklentilerinin karşılanmasında ve beklenen psikolojik tatminin sağlanarak yaşamdan aldığı hazzın ortaya çıkmasında önemli bir belirleyicidir.

ÇYK, çalışanın psikolojik ve entelektüel tatmininde belirleyici olmasına bağlı olarak işgörenin verimliliğinde, yenilikçiliğinde, stratejik katılımında da rol oynayan bir unsur olarak düşünülmelidir. Bu bakımdan, ÇYK üzerine yapılacak bir araştırma iş, işletme ve hatta sektörel verimliliğin belli koşullarının tespiti anlamına gelecektir. Bunun yanında, çalışma hayatının bireyle ilgili yönünü daha net görme imkânı sağlayacağı için iş yeri koşullarıyla ilgili düzenlemelere de esin kaynağı olabilir.

Seyahat işletmeciliği, turizm sektörü içerisinde en kritik işletmecilik alanlarından birisi, belki de en önemlisi olarak görülebilir. Zira, seyahat işletmeleri turizm olayının temelinde yer alan seyahatleri organize ederek nihai bir ürüne dönüştüren ve turiste ulaştıran işletmelerdir. Dolayısıyla, turizm sisteminin işlerliğinin en kritik faktörü ve diğer turizm işletmelerinin başarısının $\mathrm{da}$ en büyük etkileyicisi konumundadırlar. $\mathrm{Bu}$ önemi yanında seyahat işletmelerinin de emek-yoğun, turistle yüz yüze çalışmayı gerektiren ve üretim ve tüketimin aynı anda ve yerde cereyan ettiği hizmet süreçlerini içermesine bağlı olarak (Altay ve Akgül, 2010) bu işletmelerde de çalışanlar işletmenin ve sektörün verimliliği için kilit faktör konumundadır. $\mathrm{Bu}$ temel faktörün etki derecesi ise çalışanların işlerine, işletmelerine ve işkollarına karşı tutumlarını etkileyecek işletme ortamıyla ilgili faktörlere bağlı olacaktır.

$\mathrm{Bu}$ araştırmada, ÇYK'nin seyahat işletmesi çalışanlarınca hangi boyutlarda algılandığı, her bir boyuta ilişkin algılama düzeyinin işinden memnun olma ile işyerine ve iş koluna bağlllık düzeyini ne yönde etkilediği tespit edilmektedir. ÇYK'ni belirlemeye yarayan her bir ifadeye verilen cevapların bağımlı değişkenler olarak işinden memnun olma, işyerine ve işkoluna bağlılık üzerine etkileri sıralı regresyon tekniği kullanılarak analiz edilmiştir.

\section{II. ÇALIŞMA YAŞAMI KALITESİ ALGISI}

Çalışma yaşamı kalitesi, bireyler için yaşamın en önemli parçalarından birisi olan işin, işle ilgili bütün bileşenlerin ve ortamların algılanmasına dikkat çeken geniş kapsamlı bir kavramdır. Kavramın, çalışanların psikolojik olarak iş yaşamına dair algılarını içeren bir yapı olarak ele alındığı (Sirgy vd., 2001) ve bu yapının kapsamı içinde de iş doyumu, psikolojik iyilik ve genel anlamda mutluluğun olduğu anlaşılmaktadır (Gilette vd., 2013). İş doyumuyla yakın bir içeriğe sahip olmasına rağmen, Sirgy vd. (2001) bu yapının iş doyumundan farklılaştığını, hatta iş doyumunun ÇYK'nin birçok çıktısından sadece birisi olduğunu belirtmektedir.

Çalışma yaşamı kalitesi, bir bireyin işyerini oluşturan fiziksel ve psikolojik bileşenleri algılamasını ifade etmektedir. Bu algılama çalışanın kendi beklenti, bakış ve yaklaşımlarından bağımsız olamaz. Dolayısıyla, çalışanın ihtiyaçları doğrultusunda ortaya çıkan bir algılamadan bahsedilebilir. Çalışma yaşamının "kaliteli" olarak algılanması çalışanın çalışma ortamına ilişkin 
ihtiyaçlarının karşılandığını düşündürmektedir. Sirgy vd. (2001) bu bakış açısıyla ÇYK'ni, işyerinde kaynakların kullanımı, aktiviteler ve katılımın doğurduğu sonuçlar vasıtasıyla çalışanın bir dizi ihtiyacının karşılanması ve doyuma ulaştırılmasını ifade eden bir kavram olarak ele almaktadır. Diğer yandan, çalışan için işle ilgili değerlendirmesini belirleyen birçok unsur ortaya koyulabilir. Bu unsurlar; işyerinin fiziksel özellikleri, kişiler arası etkileşim ve ilişkilerin yoğunluğu, ilişkilerin seviyesi, davranış kalıpları, çalışanın sözleşmeden doğan haklarının sağlanması, ödüllendirme, vb. birçok farklı konu kadar çalışanın işinin iş-dışı alanlardaki yansımaları (toplumsal etki gibi) da olabilir.

ÇYK, işletme içinde kişiler arası ilişkiyi tanımlamakta kullanılan ortaklık, açıklık, informal ilişiki gibi boyutları öne çıkarmaktadır ve bunun yanında işletme içinde etik bir uygulama ortamının varlığına bağlı olarak arttığı belirtilmektedir (Koonmee vd., 2010). Bunun yanında, -iş ortamının psikolojik belirleyenleri kapsamında düşünülürse-, örgütsel adalet algılaması, güven ve işin anlamlı olması gibi unsurların da belirleyici olabileceği liderlik-psikolojik iyilik üzerine odaklanan çalışmalardan anlaşılmaktadır (Gilette vd., 2013). Liderliğin ÇYK'ni etkilediği ve liderin ne denli dönüştürücü (transformasyonel) olursa kalite algısının o derece arttığı Gillett vd. (2013) tarafından hemşireler üzerine yapılan alan araştırması ile ortaya koyulmaktadır. Kara vd. (2013) de konaklama işletmeleri çalışanlarının algıladıkları iyilik/iyi olma üzerinde transformasyonel liderliğin pozitif etkileri olduğunu tespit etmektedir. Sirgy vd. (2001) çalışma yaşamı kalite algısının girdileri/öncülleri olarak iş çevresi, iş gereklilikleri, yönetici davranışları ve destekleyici programlar konusundaki doyum ihtiyacını öne ç1karmaktadır.

Birçok işletme çalışma yaşamını kaliteli kılacak önlemler geliştirmekle ilgilenmektedir. Örneğin, konaklama işletmeleri için çalışanın psikolojik iyiliğinin/mutluluğunun önemi anlaşılmış bir konudur ve işletmeler bunun için çalışanı eğlendirecek, mutlu kılacak önlemler almaktadırlar (Chan, 2010). Diğer yandan, ÇYK'nin algılanması işletmenin yapısal özelliklerine göre de değişebilmektedir. Örneğin, küçük işletmelerde çalışan pazarlama yöneticilerinin büyük işletmelerde çalışan muadillerinden daha yüksek düzeyde ÇYK algılamalarına sahip oldukları Singhapakdi vd. (2010) tarafından tespit edilmiştir. Bahsedilen konu milli kültür ve işletme kültürü bağlamlarına göre de farklılaşmaktadır. Daha toplumsal özellikler gösteren kültürlerde daha bireysel özellikte olanlara göre ÇYK'nin algılanması etik vb. gibi alanların daha fazla oranda etkisinde kalmaktadır (Marta vd., 2013). Cinsiyetin de ÇYK algılanmasını etkileyen bir unsur olduğunu Singhapakdi vd. (2014) yürüttükleri alan çalışmasına dayalı olarak tespit etmişlerdir. Naude vd. (2013) ise otel ve resort konaklama işletmesi olarak ele aldıkları iki grup işletmenin ön büro çalışanları üzerinde yaptıkları test ile otel çalışanlarının daha yüksek düzeyde ÇYK algılamasına sahip olduklarını ortaya koymaktadırlar. 


\section{III. ÇYK İLE IŞE, IŞLETMEYE VE IŞ̧ KOLUNA BAĞLILIK ILIŞ̧KISİ}

ÇYK kişilerin bilişsel, duygusal ve tepkisel düzlemde ürettikleri davranışlarının açıklanmasında önemli bir olgu olarak görülmektedir. Bu olguyu ele alan birçok çalışma yapılmıştır. Bu çalışmaların ortaya koyduğu kapsam itibariyle ÇYK konusundaki algılamanın; (a) çalışma ortamından duyulan memnuniyet, (b) çalışma yaşamı dışındaki alanlarda gerçekleşen memnuniyet ve (c) genel yaşamdan duyulan memnuniyet üzerinde belirleyici etkileri olduğu tespit edilmiştir (Kara vd., 2013).

Çalışanların yüksek düzeyli bir ÇYK algısına sahip olması, temel ihtiyaçlarının karşılanması suretiyle iş doyumlarının da arttığını ortaya koymaktadır. Bu durum işletmede çalışanlarca istenen ve onları değişik yönleri ile tatmin eden koşulların hayata geçirildiğini kanıtlamaktadır. Sirgy vd., (2001)'e göre ÇYK algısının önemi çalışan-işletme etkileşiminde oluşturduğu olumlu çıktılara bağlıdır. İşyerinde mutlu olan bir çalışanın işyerine bağlılığı, istekliliği ve çaba sarf etmesi, performansı, işe yaklaşımı artmaktadır. Buna karşın, işten kaçışı, işgören devir hızı ve yabancılaşması azalmaktadır. Çalışma yaşamının kaliteli olması işe bağl1lık, iş doyumu, diğer yaşam alanlarıyla ilgili doyum (aile, boş zaman, sağlık, eğitim, arkadaşlık, kültür, sosyal statü, vd.) gibi çıtılar üretmektedir (Sirgy vd., 2001). Koonmee vd. (2010), Tayland Borsasında işlem gören farklı sektörlerden 514 işletmenin IKKY yöneticileri üzerine yaptıkları araştırmalarında, çalışma yaşamı kalitesinin iş doyumu, örgütsel bağ lılık ve takım ruhunu pozitif yönde etkilediğini tespit etmişlerdir. Kanten ve Sadullah (2012) ise çalışma yaşamı kalitesinin işe bağlılı̆̆ yerleşik bir mermer işletmesinde yaptıkları alan çalışmasıyla ortaya koymuşlardır. Seyahat işletmeleri açısından-konuyu ele alan bir çalışmaya rastlanmamakla birlikte, belli bireysel ve örgütsel faktörlerle sınırlı kalarak seyahat acentası çalışanlarının iş tatmini ve işletmeye bağlılığı gibi konuları ele alan çalışmalar vardır. Örneğin; seyahat acentalarının satış çalışanlarının iş tatmini ve örgütsel bağl1lı̆ını inceleyen Demirer vd. (2010) yöneticiye karşı duyulan sorumluluk, iş eğitimi, çalışanı güçlendirme çabaları, algılanan bireysel performans gibi sınırlı sayıdaki değişkenin ve demografik faktörlerin etkilerini karşılaştırmalı olarak ele almaktadırlar.

Yukarıda örneklendirilen çalışmalarda ÇYK'nin işinden memnun olma ve işletmeye bağlllık konusunda değişik sektörlerde etkisi tespit edilmiştir. Bu etkiler iş koluna bağl1lı konusunda bir etkinin de mümkün olabileceğini akla getirmektedir. Dolayısıyla bu çalışmada hem işinden memnun olma ve işletmeye bağlılık yeniden sorgulanmakta hem de iş koluna bağlılık ele alınmaktadır. Önceki çalışmalardan farklı olarak, çalışma yaşamı kalitesinin hangi boyutlarının işe, işletmeye ve işkoluna etkileri olduğu, bu etkilerin büyüklüğü itibariyle ve göreli önemlerine odaklanılarak sorgulanmaktadır.

\section{YÖNTEM}

Çalışmanın temel amacı ÇYK'ni ölçmede kullanılan değişkenlerin çalışanın işi, işletmesi ve işkolu ile ilgili yaklaşımını belirleyici gücünü ortaya 
koymaktır. ÇYK'ni belirlediği düşünülen farklı boyutların bu üç kapsama etkilerini tespit etmek amaçlanmaktadır. Bu sayede ÇYK kapsamında algılanan hangi boyutun ne yönde bir çıktı ürettiği, kendi aralarında göreli önem dereceleri ve bunların iş, işletme ve işkolu ile ilgili çıktıya dönüşme durumları analiz edilmektedir. Bu bağlamda her bir ÇYK değişkeninin;

a) İşinden memnun olmaya (Model 1),

b) İşletmeye bağlılı̆̆a (Model 2) ve

c) İş alanına bağlılığa (Model 3) etkileri göreli olarak tespit edilmeye çalışılmıştır.

\section{A. Veri Toplama Aracının Oluşturulması}

Çalışma yaşamı kalitesi üzerinde duran ve çalışanın çalışma yaşamını kaliteli olarak algılamasının boyutlarını sorgulayan çalışmalar bu boyutların iş doyumu yaratan boyutlarla örtüştügünü tespit etmektedir. Bu bakımdan doyum sağlayan iş ortamının özellikleri olarak; mücadeleye dönük iş, akıllıca verilen ödüller, ılımlı iş koşulları ve destekleyen iş arkadaşları, iş süreçlerinde geribildirim, çeşitlilik, otonomi, katılım ve rol çatışması olmaması, başarı ve takdir edilme gibi özellikler öne çıkmaktadır (Graham ve Messner, 1998). Sirgy vd. (2001) ise Porter Gereksinim ve Doyum Anketi (Porter Need Satisfaction Questionnaire)'ne dayalı olarak, işyerinde çalışanın tatmini için doyurulması gereken dört ihtiyaçtan bahsetmektedir. Bunlar, (a) güvenlik, ücret gibi yaşamsal ihtiyaçlar; (b) kişilerle etkileşim/ arkadaşlık ve bir sosyal gruba üye olmak gibi ihtiyaçları kapsayan sosyal ihtiyaçlar; (c) özsayg1 ve otonomiyi kapsayan ego ihtiyaçları; ve (d) kendini gerçekleştirme ihtiyaçlarıdır. Bu durumda çalışma yaşamı kalitesini ortaya koyacak unsurları çalışanın psikolojik bütünlüğü ile ilgili olanlar, fiziksel ortamla ilgili olanlar, çalışanın bilişsel gelişimi ve sağlığı ile ilgili olanlar ve çalışanın kazancı ile ilgili olanlar (araçsal) şeklinde sınıflandırmak mümkün olabilir. Bu çalışmada konu; işin kişi için ilgi çekici olması, bireysel gelişim imkânı sunması gibi araçsal özellikler, iş arkadaşlarının işlerini iyi yapmas1, yöneticilerle iyi ilişkiler gibi ilişkisel özellikler, işin gerektirdiği nitelikler konusunda bilgilendirme gibi rol unsurları, katılım, adil yönetim, işyerinde uyum, fiziksel koşulların elverişliliği, iş yükünün baş edilebilirliği, işin anlamlılığ 1 ve toplum yararına katkı gibi çalışma yaşamının algılanmasına ilişkin çok boyutlu yapıyı ortaya koyacak kapsamda ele alınmaktadır. Veri toplama amaciyla oluşturulan ankette belirtilen yönleri ölçmeye yarayan 25 ifadeye yer verilmiştir. Bu ifadeler, Türkçe'ye çevrilmesi ve alan çalışmasında kullanılarak geçerliliği ve güvenilirliği tespit edilmiş olması nedeniyle Yüksel (2004)'ten aynen alınmıştır. Ölçeğin orijinali Cacioppe ve Mock (1984)'un çalışmasında kullanılmış ve Yüksel (2004) tarafından Türkçe literatüre kazandırılmıştır.

Ölçekte eksik kaldığı ve ÇYK'nin algılanması kapsamında da önemli etkileri olabileceği düşünülen bir boyut sonradan eklenmiştir. Bu boyut "ücret algısı" boyutudur. Ücretin çalışanın algıladığı çalışma yaşamı kalitesi içinde (Tütüncü ve Demir, 2002) ve işletmeye bağlılığı üzerinde (Günlü vd., 2010) önemli etkileri söz konusudur. Ücret algılaması çalışanın motivasyonuna, performansına, işten ayrılma niyetine, işe devamına ve etik davranışlarına etki 
etmekte, işletme açısından da daha nitelikli çalışanları elde tutmanın önemli bir aracı olarak ele alınmaktadır (Demir ve Tütüncü, 2010). Ücret konusunda bir adaletsizliğin olduğu algısı ise çalışanın işten ayrılması gibi tam tersi etkiler ortaya koymaktadır (Clugston, 2000). Belirtilen önemi nedeniyle çalışanların ücret algılamalarını ölçen iki ifade ölçeğe eklenmiştir. Bu ifadeler; "aldığım ücret yaptığım iş için yeterlidir" ve "aldığım ücret beni tatmin etmektedir" ifadeleridir. $\mathrm{Bu}$ ifadeler, ücretin iş doyumu kapsamındaki önemini ortaya koymak üzere tasarlanan alan çalışmalarında kullanılan iki ifadedir. Birinci ifade Ağaç vd. (2010), ikinci ifade ise Davras ve Gülmez (2013)'den alınmıştır.

İşinden memnuniyet, işletmeye ve iş koluna bağlllık düzeylerinin ölçümünde ise daha farklı bir yol izlenmiştir. İş doyumunun düzeyi, çalışanın kendisini iyi hissetmesi ve işiyle ilgili olumlu tutum yansıtan ifadeler kullanmasına bağlı olarak ölçülmekte/belirlenmektedir (Chan, 2010). Bunun yanında, iş doyumu, memnuniyet, bağlllık gibi nihai değerlendirmelerin tek bir ifadeyle ölçülmesinin daha geçerli bir yol olduğunu düşündüren çalışmalar mevcuttur (Wanous vd., 1997; Wanous ve Hudy, 2001; Nagy, 2002; Dolbier vd., 2005). Buna bağlı olarak bu üç değişkenin ölçümü için birer yargı cümlesi kullanılmıştır. İşinden memnuniyet düzeyi "İşimden çok memnunum" ifadesi ile, işletmeye bağlılık düzeyi "Bu işletmede uzun yıllar çalışabilirim" yargısı ile ve işkoluna bağlılık düzeyi de "Bu iş alanında (seyahat acentacılı̆̆ çalışabilirim" ifadesi yardımıyla ölçülmüştür. ÇYK'ni ölçen 25 ifadeye ilave edilen 2 adet ücret algısı ifadeleri ve 3 adet de bağımlı değişkenlere dair ifadeleri ekleyince ölçekte kullanılan toplam ifade sayısı 30 olmuştur. Hem ücret algılamasını da kapsayan ÇYK ifadeleri hem de işinden memnuniyet, işletmeye ve işkoluna bağlılığı ölçen ifadelere verilecek cevaplar (1) "kesinlikle katılmıyorum" - (5) "kesinlikle katılıyorum" şeklinde ölçeklendirilen 5'li Likert tipi ölçek kullanılarak elde edilmiştir. Ölçekte ayrıca cinsiyet, yaş, eğitim ve ilgili işte çalışma yılı kategorik olarak, görev ise açık uçlu bir şekilde sorulmuştur.

\section{B. Örnekleme}

Örneklemede olasılığa dayalı olmayan bir yol izlenmiştir. Bu kapsamda, örneğin yoğun bir şekilde havayolu bileti satan ve uluslararası seyahat organizasyonu yapan acentalar yanında daha küçük ölçekli ve yurtiçi turlar ve küçük çaplı organizasyonlar yapan acentaların da örnekleme dâhil olması açısından farklı bölgelerde anket çalışması yürütülmüş̧ür. Aynı amaca yönelik olarak anketin İstanbul, Ankara gibi iki metropol yanında İzmit, Sakarya, Bursa, Eskişehir gibi daha az kurumsal acentacılığın görülmesinin muhtemel olduğu yerlerde uygulanması tercih edilmiştir. Ancak Bursa'da acentalara ulaşımla ilgili yaşanan sorun nedeniyle burası örneklemden çıkarılmıştır. Bu bakımdan amaçlı bir örnekleme yolu seçilmiştir denebilir. 2014 y1lı itibariyle Türkiye Seyahat Acentaları Birliği (TÜRSAB)'ne üye İstanbul'da toplam 2677, Ankara'da 557, Sakarya'da 30, Kocaeli'de 85 ve Eskişehir'de 59 seyahat acentası faaliyettedir (TURSAB, 2014). Bu dönemde Sosyal Güvenlik Kurumu (SGK) verileri itibariyle tüm Türkiye genelindeki 7.246 acentada 48.121 kişi sigortalı olarak çalışmaktadır (SGK, 2014). Örneklem bölgesindeki seyahat acentaları sayısının 
Türkiye toplamı içindeki payı göz önünde bulundurularak toplam çalışan sayısının da en az yarısının örneklem bölgesinde çalıştığını söylemek mümkündür. Diğer yandan, geçerli bir ölçüm yapabilmek için ölçekte kullanılan ifade sayısının 5 katı oranında bir katılıma ulaşılması gerektiği uzmanlarca önerilmektedir (Hair vd., 2006). Ankette 30 ifade yer aldığından 150 adet katılım kritik sayı olarak belirlenmiş ve bu sayının altına düşülmemesi konusunda gayret gösterilmiştir. Anket çalışmasında kolayda örnekleme yolu ile ulaşılabilen katılımcıların çalışmaya katılımları yoluna gidilmiştir. Ulaşılan sayı hesaplanan kritik değeri aştığı için de yeterli görülmüştür.

\section{BULGULAR}

Araştırmaya katılanların \%59,5'i bayan, \%53'ü 30 ve altı yaş grubundan, $\%$ 48,3'ü lisans ve lisansüstü mezunudur. \% 13,8'i bir yıldan az süredir, \% 14,7'si 1-2 yıl arası, \%14,7'si 2-3 y1l aras1, \%15,5'i 3-4 yıl aras1, \% 12,5'i 4-5 y11 aras1 ve $\%$ 28,4'ü de 5 yıldan fazla bir zamandır halen devam ettikleri işte çalışmaktadır. Katılımcilardan \% 40,1'i İstanbul, \% 22,0'1 Ankara ve \% 37,9'u da Sakarya, İzmit ve Eskişehir illerinde yerleşik bir acentada çalışmaktadır. Katılımcıların \% 9,9'u acenta sahibi ya da müdür; \% 11,2'si bölüm yöneticisi, şef veya supervisor; \% 7,3'ü bilet satış memuru; \% 6,9'u operasyon görevlisi; \% 23,3'ü satış temsilcisi; \% 25,4'ü seyahat danışmanı ve \% 8,6'sı da diğer yanıtını vermiştir. Acenta sahibi ve müdür kategorisini oluşturan katılımcılar görevlerini acenta müdürü, acenta sorumlusu ve genel müdür yardımcısı olarak ifade edenlerdir. Bölüm yöneticisi, şef ve supervisor grubunu oluşturanlar görevlerini, satış müdürü, kontrat müdürü, operasyon müdürü, biletleme bölüm müdürü, hac-umre bölüm müdür ve müdür yardımcılığı gibi detaylı ifade edenlerdir. Diğer olarak görülenler ise AR-GE, acenta çalışanı, muhasebe, halkla ilişkiler, hazırlık ve üretim, destinasyon planlama, fiyat belirleme, grafik tasarım, danışma, satınalma, stajyer gibi görevler icra edenlerdir (Tablo 1).

Tablo 1. Katılımcıların Demografik ve İșle İlgili Özellikleri

\begin{tabular}{|c|c|c|c|c|c|}
\hline CINSIYYET & $\mathbf{N}$ & $\%$ & YASS & $\mathbf{N}$ & $\%$ \\
\hline Bay & 94 & 40,5 & 30 ve alt 1 & 123 & 53,0 \\
\hline Bayan & 138 & 59,5 & $31-35$ & 60 & 25,9 \\
\hline \multicolumn{3}{|l|}{ EĞİTíM } & 36 ve üstü & 49 & 21,1 \\
\hline Lise ve dengi & 47 & 20,3 & \multicolumn{3}{|c|}{ ÇALIŞMA YILI } \\
\hline Önlisans & 69 & 29,7 & 1 y1ldan az & 32 & 13,8 \\
\hline Lisans-Lisansüstü & 112 & 48,3 & $1-2$ y1l & 34 & 14,7 \\
\hline Cevapsiz & 4 & 1,7 & $2-3$ y1l & 34 & 14,7 \\
\hline \multicolumn{3}{|l|}{ GÖREV } & 3-4 y1l & 36 & 15,5 \\
\hline Acenta Sahibi ve Müdür & 23 & 9,9 & $4-5$ y1l & 29 & 12,5 \\
\hline $\begin{array}{l}\text { Bolum Yöneticisi, Şef } \\
\text { ve Supervisor }\end{array}$ & 26 & 11,2 & 5 yıldan fazla & 66 & 28,4 \\
\hline Bilet Satış & 17 & 7,3 & Cevapsiz & 1 & ,4 \\
\hline Operasyon Görevlisi & 16 & 6,9 & \multicolumn{3}{|c|}{ ŞEHİR } \\
\hline Satış Temsilcisi & 54 & 23,3 & İstanbul & 93 & 40,1 \\
\hline Seyahat Danışmanı & 59 & 25,4 & Ankara & 51 & 22,0 \\
\hline Diğer & 20 & 8,6 & $\begin{array}{l}\text { Sakarya-İzmit- } \\
\text { Eskișehir }\end{array}$ & 88 & 37,9 \\
\hline Cevapsiz & 17 & 7,3 & & & \\
\hline
\end{tabular}


Katılımcıların verdikleri yanıtları frekans dağılımı, aritmetik ortalama ve standart sapmaları Tablo 2'de gösterilmektedir. Tabloya göre acenta çalışanlarının ÇYK algılamaları birçok değişken itibariyle yüksektir.

Tablo 2. ÇYK ve Bağımlı Değişkenlere İlişkin Frekans Tablosu

\begin{tabular}{|c|c|c|c|c|c|c|c|}
\hline & & & 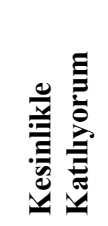 & E & 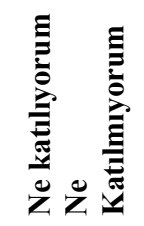 & 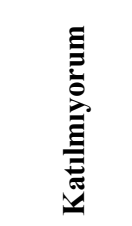 & 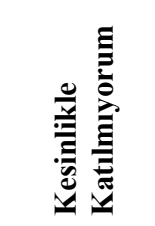 \\
\hline İfadeler & A.O. & S.S. & F (\%) & F (\%) & F (\%) & F (\%) & F (\%) \\
\hline $\begin{array}{l}\text { 1) İşim benim için ilgi çekici } \\
\text { bir iştir. }\end{array}$ & 4,45 & \begin{tabular}{|l|}
, 75 \\
\end{tabular} & $2(0,9)$ & $2(0,9)$ & $19(8,2)$ & $74(31,9)$ & $135(58,2)$ \\
\hline $\begin{array}{l}\text { 2) Birlikte çalıştığım kişiler } \\
\text { işlerini iyi yapmaktadır. }\end{array}$ & 4,31 & \begin{tabular}{|l|}
, 79 \\
\end{tabular} & $2(0,9)$ & $5(2,2)$ & $22(9,5)$ & $93(40,1)$ & $110(47,4)$ \\
\hline $\begin{array}{l}\text { 3) Birlikte çalıştığım kişilerin } \\
\text { yaptıkları çalışmalara katılmak } \\
\text { ve onlara katkıda bulunmak } \\
\text { için yeterli firsatım vardır }\end{array}$ & 4,33 & ,71 & $1(0,4)$ & $4(1,7)$ & $15(6,5)$ & $\begin{array}{r}109 \\
(47,0)\end{array}$ & $103(44,4)$ \\
\hline $\begin{array}{l}\text { 4) Çalıştığım ortamda bireysel } \\
\text { gelişimim teşvik edilmektedir }\end{array}$ & 4,20 & \begin{tabular}{|l|}
, 85 \\
\end{tabular} & $1(0,4)$ & $10(4,3)$ & $30(12,9)$ & $92(39,7)$ & $99(42,7)$ \\
\hline $\begin{array}{l}\text { 5) İşyerimin atmosferi iyi } \\
\text { çalış̧abilmeye elverişlidir }\end{array}$ & 4,31 & ,77 & 0 & $5(2,2)$ & $29(12,5)$ & $86(37,1)$ & $112(48,3)$ \\
\hline $\begin{array}{l}\text { 6) Bu işletmede çalışmamın } \\
\text { benim için bir şans olduğu } \\
\text { kanısındayım }\end{array}$ & 4,17 & ,86 & $1(0,4)$ & $8(3,4)$ & $40(17,2)$ & $84(36,2)$ & $99(42,7)$ \\
\hline $\begin{array}{l}\text { 7) Çalıştı̆̆ım bölümde yapılan } \\
\text { işin kalitesi yüksektir }\end{array}$ & 4,44 & \begin{tabular}{|l|}
, 70 \\
\end{tabular} & 0 & $1(0,4)$ & $25(10,8)$ & $76(32,8)$ & $130(56,0)$ \\
\hline $\begin{array}{l}\text { 8) Yöneticilerimle iletişimim } \\
\text { iyidir }\end{array}$ & 4,57 & ,62 & $1(0,4)$ & 0 & $11(4,7)$ & $72(31,0)$ & $148(63,8)$ \\
\hline $\begin{array}{l}\text { 9) Yaptığım işin gereklerini ve } \\
\text { benden beklentileri biliyorum }\end{array}$ & 4,59 & \begin{tabular}{|l|}
, 59 \\
\end{tabular} & 0 & $2(0,9)$ & $7(3,0)$ & $73(31,5)$ & $150(64,7)$ \\
\hline $\begin{array}{l}\text { 10) İşletmem yüksek } \\
\text { kapasitede çalışmaktadır }\end{array}$ & 4,25 & \begin{tabular}{|l|}
, 79 \\
\end{tabular} & $2(0,9)$ & $3(1,3)$ & $30(12,9)$ & $96(41,4)$ & $101(43,5)$ \\
\hline $\begin{array}{l}\text { 11) İşle ilgili yeni fikirler } \\
\text { geliştirme ve yeni fikirlerle } \\
\text { katkıda bulunma olanağım } \\
\text { vardır. }\end{array}$ & 4,26 &, 81 & $2(0,9)$ & $6(2,6)$ & $24(10,3)$ & $97(41,8)$ & $103(44,4)$ \\
\hline $\begin{array}{l}\text { 12) İşle ilgili yeterli sıklıkta } \\
\text { toplantılar yapılmaktadır }\end{array}$ & 3,85 & 1,04 & $5(2,2)$ & $23(9,9)$ & $46(19,8)$ & $84(36,2)$ & $74(31,9)$ \\
\hline $\begin{array}{l}\text { 13) Yöneticilerimiz bizlere } \\
\text { karşı adildirler. }\end{array}$ & 4,26 & , 88 & $4(1,7)$ & $5(2,2)$ & $30(12,9)$ & $80(34,5)$ & $113(48,79$ \\
\hline $\begin{array}{l}\text { 14) İşyerimin fiziksel koşulları } \\
\text { çalışmam için yeterlidir. }\end{array}$ & 4,33 & \begin{tabular}{|l|}
, 78 \\
\end{tabular} & $1(0,4)$ & $5(2,2)$ & $24(10,3)$ & $\begin{array}{r}878 \\
(37,9) \\
\end{array}$ & $114(49,1)$ \\
\hline \begin{tabular}{|l|} 
15) İşyerinde farklı \\
bölümlerden arkadaşlarla uyum \\
ve birlik içinde çalışırız \\
\end{tabular} & 4,42 & ,70 & $1(0,4)$ & $2(0,9)$ & $17(7,3)$ & $91(39,2)$ & $121(52,2)$ \\
\hline $\begin{array}{l}\text { 16) İşimizle ilgili kararlar } \\
\text { alınırken fikrim sorulur ve } \\
\text { katılımım istenir. }\end{array}$ & 4,20 & ,90 & $4(1,7)$ & $9(3,9)$ & $25(10,8)$ & $91(39,2)$ & $103(44,4)$ \\
\hline
\end{tabular}


Yönetim ve Ekonomi 22/1 (2015) 239-256

\begin{tabular}{|c|c|c|c|c|c|c|c|}
\hline $\begin{array}{l}\text { 17) Bölümümüzde işle ilgili } \\
\text { yaptığımız toplantılar verimli } \\
\text { geçer. }\end{array}$ & 4,08 & ,94 & $3(1,3)$ & $13(5,6)$ & $38(16,4)$ & $86(37,1)$ & $92(39,7)$ \\
\hline $\begin{array}{l}\text { 18) Yöneticilerimiz gerekli } \\
\text { olan teknik kapasite ve } \\
\text { yeteneğe sahiptir. }\end{array}$ & 4,21 & ,92 & $3(1,3)$ & $9(3,9)$ & $34(14,7)$ & $77(33,2)$ & $109(47,0)$ \\
\hline $\begin{array}{l}\text { 19) Sahip olduğum bilgi ve } \\
\text { beceri düzeyim yaptığım iş için } \\
\text { yeterlidir. }\end{array}$ & 4,42 & ,67 & 0 & $1(0,4)$ & $21(9,1)$ & $90(38,8)$ & $120(51,7)$ \\
\hline $\begin{array}{l}\text { 20) Üzerimdeki iş yükü ve } \\
\text { yarattı̆̆ stres başa } \\
\text { çıabileceğim düzeydedir. }\end{array}$ & 4,19 &, 79 & $2(0,9)$ & $3(1,3)$ & $35(15,1)$ & $\begin{array}{r}101 \\
(43,5)\end{array}$ & $91(39,2)$ \\
\hline $\begin{array}{l}\text { 21) Yaptığım iş, işletmemin } \\
\text { başarısı için önemlidir. }\end{array}$ & 4,49 & ,67 & $1(0,4)$ & $1(0,4)$ & $15(6,5)$ & $81(34,9)$ & $134(57,8)$ \\
\hline $\begin{array}{l}\text { 22) Bölümümüz verimli } \\
\text { çalışmaktadır (zaman ve } \\
\text { maliyetler açısından). }\end{array}$ & 4,33 &, 74 & $2(0,9)$ & $1(0,4)$ & $24(10,3)$ & $97(41,8)$ & $108(46,6)$ \\
\hline $\begin{array}{l}\text { 23) Yöneticilerimiz çalışanların } \\
\text { ihtiyaçlarının farkındadırlar ve } \\
\text { bunları karşılamak için } \\
\text { uğraşırlar. }\end{array}$ & 4,06 & 88 & $1(0,4)$ & $12(5,2)$ & $42(18,1)$ & $93(40,1)$ & $84(36,2)$ \\
\hline $\begin{array}{l}\text { 24) Burada ürettiğimiz mal ve } \\
\text { hizmetler toplum yararınadır. }\end{array}$ & 4,36 & ,77 & $2(0,9)$ & $2(0,9)$ & $25(10,8)$ & $85(36,6)$ & $118(50,9)$ \\
\hline $\begin{array}{l}\text { 25) İşletmeme en yüksek } \\
\text { katkıy yapmak için çabalarım } \\
\text { ve yapabileceğimin en iyisini } \\
\text { yapmaktan hoşlanırım. }\end{array}$ & 4,60 & ,63 & $1(0,4)$ & $2(0,9)$ & $7(3,0)$ & $69(29,7)$ & $153(65,9)$ \\
\hline $\begin{array}{l}\text { 26) Aldığım ücret yaptığım iş } \\
\text { için yeterlidir. }\end{array}$ & 3,72 & 1,10 & $12(5,2)$ & $21(9,1)$ & $48(20,7)$ & $89(38,3)$ & $62(26,7)$ \\
\hline $\begin{array}{l}\text { 27) Aldığım ücret beni tatmin } \\
\text { etmektedir. }\end{array}$ & 3,54 & 1,13 & $13(5,6)$ & $9(12,5)$ & $60(25,9)$ & $78(33,7)$ & $52(22,4)$ \\
\hline 28) İşimden çok memnunum. & 4,11 & 90 & $3(1,3)$ & $5(2,2)$ & $50(21,6)$ & $78(33,6)$ & $96(41,4)$ \\
\hline $\begin{array}{l}\text { 29) Bu işletmede uzun yıllar } \\
\text { çalışabilirim. }\end{array}$ & 3,97 & 1,03 & $6(2,6)$ & $14(6,0)$ & $50(21,6)$ & $73(31,5)$ & $89(38,4)$ \\
\hline $\begin{array}{l}\text { 30) Seyahat acentacılığı } \\
\text { alanında uzun yıllar } \\
\text { çalışabilirim. }\end{array}$ & 4,07 & 1,01 & $5(2,2)$ & $13(5,6)$ & $42(18,1)$ & $72(31,0)$ & $100(43,1)$ \\
\hline
\end{tabular}

Katılımcıların ÇYK'ni oluşturan farklı etkenler konusundaki değerlendirmelerinin onların işlerinden memnun olma, işletmeye ve işkoluna bağlılıkları üzerine etkileri sıralı regresyon testi ile analiz edilmiştir. Sıralı regresyonun tercih edilmesinin temel nedeni, etki analizi ve model testi için araştırma sürecinde çoklu regresyon analizinin düşünülmesine rağmen verinin bu analizin uygulanmasını imkânsız kılmasıdır. Bilindiği gibi çoklu regresyon ya da doğrusal regresyon uygulamasının temel varsayımlarından birisi verinin normal dağılmasıdır (Hair vd., 2006). Bu araştırmada elde edilen verinin normal dağılıma uymadığı tespit edilmiştir. Buna bağlı olarak da aralıklı düzeyde ölçülmüş olsa da verinin sıralı düzeyde ölçüldüğü kabulüne dayalı bir analiz olan sıralı regresyon analizinin kullanılması ile sonuca gidilmiştir. 
Siralı Regresyon, elde edilen verinin doğrusal regresyonun uygulanması için gerekli ön koşulları sağlamadığı durumlarda ve sıralı düzeyde ölçülmüş veri üzerinden etki analizlerinde kullanılmaktadır (Şerbetçi ve Özçomak, 2013). Doğrusal regresyon, bağımlı değişkene verilen cevaplar ile bağımsız değişkenlere verilen cevapların ağırlıklandırılmış kombinasyon değerleri arasındaki farklılıkların kareleri toplamını minimize etmeye dayalıdır. Bu nedenle her bir katılımcının ilgili değişkene verdiği cevapların farkı mutlak değer olarak dikkate alınır. Sıralı regresyonda ise böyle bir şart yoktur. Cevaplama kategorileri keyfidir (IBM, 2011). Siralı regresyon, bağımlı değişkenin sıralı düzeyde ölçüldüğü durumlarda kullanılmaktadır. Sıralı düzeyde ölçülmüş bağımlı değişkenleri açıklamada yegâne alternatif modeldir. Bağımlı değişkenin en az üç kategoride ölçülmüş olması, ölçümün küçükten büyüğe bir sıra takip etmesi gerekir (Şerbetçi ve Özçomak, 2013). Bu çalışmada bağımlı değişken kesinlikle katılmıyorumkesinlikle katılıyorum aralığında beşli bir sıralama dahilinde ölçülmüştür. Sıralı regresyon ölçümleri için yapılan önerilere de uygun olacak şekilde küçükten büyüğe (katılım derecesi itibariyle) bir sıralama elde edilmiştir. Sıralı regresyon analizinde bağımlı değişken sıralı düzeyde ölçülmüş olmalıdır. Bu çalışmada test edilen üç ayrı bağımlı değişken Likert tipi ölçekle ölçülmüştür. Likert tipi ölçek bazı araştırmacılarca sıralı bir ölçek olarak tanımlanmaktadır (bkz. Hox, 2010:141). Bağımsız değişkenler aralıklı ve kategorik düzeylerde ölçülmüş olarak değerlendirilir. Aralarında ya eşit aralık ya da kategorik ilişki olduğu varsayılır.

SPSS programı 5 ayrı sıralı regresyon fonksiyonu yürütmektedir. Bunlar; logit, complementary log-log, negatif log-log, probit ve cauchit fonksiyonlardır (Tablo 3). Bu fonksiyonlardan complamentary log-log fonksiyonu bu çalışma için uygun görülmüştür. Çünkü, kategoriler arasında eşit bir dağılım söz konusu değildir. Bunun yanında ölçeklendirmeye de bağlı olarak üst kategorilerde cevaplanma sıklığı daha yüksektir. Bu durum complementary log-log fonksiyonu ile regresyon analizini gerekli kılmaktadır (IBM, 2011). Çalışmada tüm ÇYK değişkenleri kovaryans ve ölçülen demografik değişkenler de faktör olarak regresyon analizine sokulmuş ve üç ayrı bağımlı değişken üzerindeki etkileri sırasıyla test edilmiştir. Her bir model dahilinde anlamlı etki üretmeyen değişkenler modellerden çıkarılarak nihai modeller ve bu modellere ait değerler elde edilmiştir.

Tablo 3. Sıralı Regresyon Fonksiyonları (IBM, 2011)

\begin{tabular}{|l|l|l|} 
Fonksiyon & Form & Uygulama \\
\hline Logit & $\log (\mathrm{x} /(1-\mathrm{x}))$ & Eşit oy almış kategorilere uygulanır \\
\hline $\begin{array}{l}\text { Complementary } \log - \\
\log \end{array}$ & $\log (-\log (1-\mathrm{x}))$ & Üst kategorilerin daha olası olduğu durumlarda uygulanır \\
\hline Negative $\log -\log$ & $-\log (-\log (\mathrm{x}))$ & Alt kategorilerin daha olası olduğu durumlarda uygulanır \\
\hline Probit & $\mathrm{F}^{-1}(\mathrm{x})$ & Gizil değişkenin normal dağıldığı durumlarda uygulanır \\
\hline $\begin{array}{l}\text { Cauchit (inverse } \\
\text { Cauchy) }\end{array}$ & $\tan (\pi(\mathrm{x}-0.5))$ & $\begin{array}{l}\text { Gizil değişkenin çok sayıda ekstrem değer ürettiği } \\
\text { durumlarda uygulanır }\end{array}$ \\
\hline
\end{tabular}


Paralel eğriler testi belirlenen regresyon katsayılarının sıralı ölçülmüş olan değişkene ait tüm kategorilerde eşit olduğunu sınar. Diğer bir deyişle paralellik varsayımı gereği parametrelerin tahmini değerlerinin bağımlı değişkenin tüm kategorileri için aynı kesme noktasından geçmeleri gerekir (Akın ve Şentürk, 2012). Bu testin anlamlılığ 10,05 'den büyük çıkması "parametre tahmin değerlerinin bağımlı değişkenin tüm kategorileri için aynı kesme noktasından geçtiği" şeklinde kurulan H0 hipotezinin kabulü, "farklı kesme noktalarından geçer" şeklindeki H1 hipotezinin reddi anlamına gelir. Bu çalışmada Tablo 4'te görüldüğü gibi, her üç model için de paralel eğriler testi sonuçları anlamlı bulunmamıştır ve tahmin değerlerinin aynı kesme noktalarından geçtiği, kategoriler arasında katsayıların eşit dağıldığ varsayımının sağlandığ 1 tespit edilmiştir.

Tablo 4. Paralel Eğriler Testi Sonuçları

\begin{tabular}{|c|c|c|c|c|c|c|c|c|c|c|c|c|}
\hline & \multicolumn{4}{|c|}{ Model 1} & \multicolumn{4}{|c|}{ Model 2} & \multicolumn{4}{|c|}{ Model 3} \\
\hline & 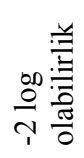 & 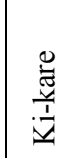 & $\frac{4}{7}$ & 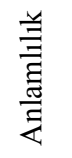 & 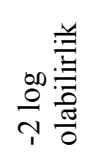 & $\frac{\mathscr{\pi}}{\frac{\pi}{i}}$ & $\frac{4}{0}$ & $\begin{array}{l}\text { 当 } \\
\bar{\Xi} \\
\text { 皇 }\end{array}$ & 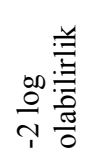 & $\frac{\mathscr{\pi}}{\frac{\pi}{i}}$ & $\frac{4}{7}$ & $\begin{array}{l}\frac{y}{Z} \\
\frac{\bar{Z}}{E} \\
\frac{\Xi}{Z}\end{array}$ \\
\hline $\begin{array}{l}\text { Null } \\
\text { hipotez } \\
\text { i } \\
\text { Genel }\end{array}$ & $\begin{array}{l}300,5 \\
8 \\
282,9 \\
9\end{array}$ & $\begin{array}{c}17,5 \\
8\end{array}$ & 48 & $\begin{array}{l}1,00 \\
0\end{array}$ & $\begin{array}{l}333,2 \\
9 \\
311,9 \\
0\end{array}$ & $\begin{array}{l}21,3 \\
8\end{array}$ & 48 & $\begin{array}{l}1,00 \\
0\end{array}$ & $\begin{array}{l}315,2 \\
1 \\
281,1 \\
8\end{array}$ & $\begin{array}{l}34,0 \\
3\end{array}$ & 27 & $\begin{array}{l}, 16 \\
5\end{array}$ \\
\hline
\end{tabular}

Bağlantı fonksiyonu: Complementary Log-log.

Siralı regresyon analizinde modelin anlamlılı̆̆ ki-kare testi ile tespit edilmektedir. Ki-kare testinin anlamlılığ $1 \quad(p<0,05)$ modelin uygunluğunu göstermektedir. Bu çalışmada her üç model için de uygun olduğuna dair veri elde edilmiştir (Tablo 5).

Tablo 5. Model Uyumu Sonuçları

\begin{tabular}{|c|c|c|c|c|c|c|c|c|c|c|c|c|}
\hline & \multicolumn{4}{|c|}{ Model 1} & \multicolumn{4}{|c|}{ Model 2} & \multicolumn{4}{|c|}{ Model 3} \\
\hline & 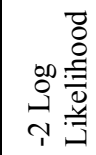 & $\frac{\ddot{\pi}}{\frac{\pi}{\pi}}$ & 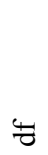 & 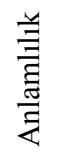 & 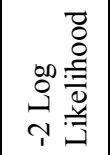 & 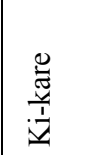 & $\frac{4}{0}$ & $\begin{array}{l}\text { 兰 } \\
\bar{\Xi} \\
\text { 严 }\end{array}$ & 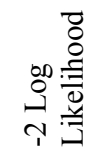 & 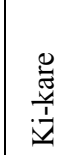 & 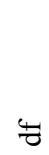 & 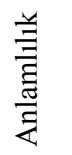 \\
\hline $\begin{array}{l}\text { Intercept } \\
\text { only } \\
\text { Final }\end{array}$ & $\begin{array}{l}510,92 \\
300,58\end{array}$ & 210,34 & 16 &, 000 & $\begin{array}{l}557,75 \\
333,29\end{array}$ & 224,45 & 16 &, 000 & $\begin{array}{l}394,45 \\
315,21\end{array}$ & 99,24 & 9 &, 000 \\
\hline
\end{tabular}

Modelin uyumuna ilişkin ikinci veri, sıralı regresyon analizinin ürettiği "uyum iyiliği (goodness of fit)" değerleridir. Bu değerler de yine ki-kare değeri ve onun anlamlılığı üzerinden yorumlanmaktadır. Anlamlı çıkan sonuçlar modelin uyumu hakkında sorun olduğunu ortaya koymaktadır. Bu çalışmada elde edilen veriler Model 3 için elde edilen Pearson değerinin anlamlılığ 1 dışında modelin 
uyum iyiliğini yansıtmaktadır (Tablo 6). Bu beklenmeyen değer ise yukarıdaki model anlamlılı̆̆ı gözetilerek önemli görülmemiştir.

Tablo 6. Uyum İyiliği Test Sonuçları

\begin{tabular}{|c|c|c|c|c|c|c|c|c|c|}
\hline & \multicolumn{3}{|c|}{ Model 1} & \multicolumn{3}{|c|}{ Model 2} & \multicolumn{3}{|c|}{ Model 3} \\
\hline & 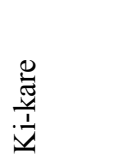 & $\frac{4}{7}$ & 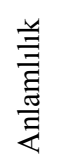 & 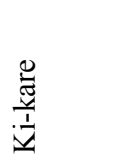 & 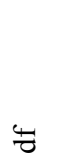 & 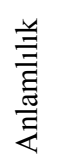 & 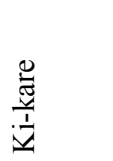 & 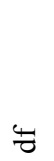 & 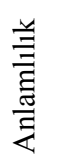 \\
\hline Pearson & 623,350 & 756 & 1,000 & 504,532 & 712 & 1,000 & 333,962 & 283 & ,020 \\
\hline Sapma & 358,392 & 756 & 1,000 & 394,850 & 712 & 1,000 & 244,587 & 283 & ,952 \\
\hline
\end{tabular}

Bağımlı değişkenler ile bu değişkenleri açıkladığı düşünülen ifadeler arasındaki ilişkiye $\left(\mathrm{R}^{2}\right)$ dair üretilen katsayıları ortaya koyan Tablo 7'ye göre bu ilişki katsayıları üç ayrı test itibariyle de yüksek çıkmıştır. Bu durum sıralı regresyon analizi için verinin uygunluğunu ortaya koymaktadır.

Tablo 7. Pseudo $\mathrm{R}^{2}$ Değerleri

\begin{tabular}{|l|l|l|l|}
\hline & Model 1 & Model 2 & Model 3 \\
\hline Cox ve Snell &, 626 &, 650 &, 308 \\
\hline Nagelkerke &, 688 &, 698 &, 334 \\
\hline McFadden &, 409 &, 394 &, 144 \\
\hline
\end{tabular}

Aşağıda Model 1 için parametre tahminleri, standart hata ve anlamlılık değerleri verilmektedir (Tablo 8). Modelde 4 eşik değeri hesaplanmıştır. Eşik değerler (ya da kesme noktaları da denmektedir) kategori sayısının bir eksiği kadar hesaplanır ve bu değerlerle bağımlı değişkene dair çıkarsamalarda bulunulur. Bağımlı değişken kategorilerinden birisi referans kategorisi olarak ele alınır ve diğerleri bu kategori üzerinden ve ardışık kategoriler için kümülatif değerler olarak tahmin edilir. Referans kategorisi ise en yüksek değer alan ve kümülatif olarak "1"e eşit olan kategoridir (Akın ve Şentürk, 2012). Bu değerler bağımlı değişkenin farklı kategorilerine ilişkin olasılık değerlerinin hesaplanmasıyla belirlenmektedir. Dört eşik değerine ilişkin olasılık değeri de anlamlı bulunmuştur. Bu durumda dört kategori arasındaki değişimi açıklayacak bağımsız değişkenleri tespit etmek anlamlı bir yol olacaktır.

İşimden çok memnunun ifadesini açıklayan değişkenler; "bu işletmede çalışmanın benim için şans olduğu kanısındayım”, "İşletmem yüksek kapasitede çalışmaktadır", "Yöneticilerimiz çalışanların ihtiyaçlarının farkındadırlar ve bunları karşılamak için uğraşırlar", "İşletmeme en yüksek katkıyı yapmak için çabalarım ve yapabileceğimin en iyisini yapmaktan hoşlanırım" ve "aldığım ücret beni tatmin etmektedir" ifadeleridir. Bu bakımdan işletmesini kendisi için bir şans olarak görmek, işletmesinin yüksek kapasiteli çalıştığını düşünmek, yöneticilerinin çalışanlarının ihtiyaçlarına odaklandıklarını görmek, işletme için yüksek katkı peşinde olmak ve ücretinden tatmin olmak konusundaki düzey arttıkça işinden memnun olma düzeyi artmaktadır. Bu her bir değişkenin değeri 1 birim arttırıldığında bağımlı değişkeni sahip oldukları tahmin oranında 
artıracaklardır. Örneğin işletmede çalışmayı şans olarak görme konusunda düzey bir birim arttırılırsa iş doyumuna bunun etkisi 0,33 birimlik artış şeklinde olacaktır. Bunun yanında çalışma yılı 5 yıl ve üzeri olanlar temel alındığında 1-2 yıl deneyime sahip olmakla 3-4 yıl deneyime sahip olmak iş doyumunu negatif yönde etkilemektedir. Buradan hareketle kısmen de olsa yıl arttıkça iş doyumunun düşeceği yolunda bir durum ortaya çıkmaktadır. Benzer bir durum görevler için de söz konusudur. Operasyon görevlisi, satış temsilcisi ve seyahat danışmanı olarak çalışmak iş doyumuna negatif etki üretmektedir (Tablo 8).

Seyahat acentası satış çalışanlarının iş tatminini ölçen Demirer vd. (2010) iş tatminini etkileyen faktör olarak işindeki algılanan başarı ve denetçiye karş1 duyulan sorumluluk algılamasını tespit etmiştir. İşindeki performans düzeyine ilişkin algılaması içsel bir değerlendirmeyi ortaya koymaktadır. Bu durumda seyahat acentası çalışanlarının işinden memnuniyetini belirleyen temel faktörlerin içsel faktörler olması konusu literatüre uygun olarak tespit edilmiştir denebilir.

Tablo 8. "İşimden çok memnunum" İfadesini Açıklayan Değişkenler ve Parametre Tahminleri (Model 1)

\begin{tabular}{|c|c|c|c|c|c|c|}
\hline & & Tahmin & S.Hata & Wald & df & Sig. \\
\hline io & {$[\mathrm{Bag} 01=1,00]$} & 3,103 & 1,005 & 9,526 & 1 &, 002 \\
\hline 气 & {$[\mathrm{Bag} 01=2,00]$} & 4,307 & ,943 & 20,864 & 1 &, 000 \\
\hline$\stackrel{4}{\bar{m}}$ & {$[\mathrm{Bag} 01=3,00]$} & 6,696 & ,969 & 47,791 & 1 &, 000 \\
\hline & {$[\mathrm{Bag} 01=4,00]$} & 8,473 & 1,033 & 67,234 & 1 &, 000 \\
\hline & $\begin{array}{l}\text { 6) Bu işletmede çalışmamın benim için } \\
\text { bir şans olduğu kanısındayım }\end{array}$ &, 337 &, 124 & 7,446 & 1 & ,006 \\
\hline & $\begin{array}{l}\text { 10) İşletmem yüksek kapasitede } \\
\text { çalışmaktadır }\end{array}$ &, 500 & 146 & 11,690 & 1 & ,001 \\
\hline & $\begin{array}{l}\text { 23) Yöneticilerimiz çalışanların } \\
\text { ihtiyaçlarının farkındadırlar ve bunları } \\
\text { karşılamak için uğraşırlar. }\end{array}$ & ,381 & ,132 & 8,338 & 1 & ,004 \\
\hline & $\begin{array}{l}\text { 25) İşletmeme en yüksek katkııı yapmak } \\
\text { için çabalarım ve yapabileceğimin en } \\
\text { iyisini yapmaktan hoşlanırım. }\end{array}$ & ,684 & ,164 & 17,449 & 1 &, 000 \\
\hline ప & $\begin{array}{l}\text { 27) Aldığım ücret beni tatmin } \\
\text { etmektedir. }\end{array}$ & ,418 & 103 & 16,555 & 1 & ,000 \\
\hline ב & [c.yili=1] &,- 646 & ,347 & 3,460 & 1 &, 063 \\
\hline 光 & [c.yili=2] & $-1,287$ & ,342 & 14,142 & 1 &, 000 \\
\hline & \begin{tabular}{|l} 
c.yili=3] \\
\end{tabular} &,- 623 &, 340 & 3,358 & 1 & ,067 \\
\hline & [c.yili=4] &,- 855 & ,345 & 6,161 & 1 &, 013 \\
\hline & {$[$ c.yili=5] } &,- 371 & ,375 & ,981 & 1 &, 322 \\
\hline & {$[$ c.yili=6] } & $0 \mathrm{a}$ & & . & 0 & \\
\hline & {$[$ gorevNom $=1,00]$} &,- 048 & ,501 &, 009 & 1 & ,924 \\
\hline & {$[$ gorevNom $=2,00]$} &,- 437 & ,448 & ,954 & 1 & ,329 \\
\hline & {$[$ gorevNom $=3,00]$} &, 020 &, 515 &, 002 & 1 & ,968 \\
\hline & [gorevNom=4,00] & $-1,270$ & ,489 & 6,748 & 1 &, 009 \\
\hline & [gorevNom=5,00] &,- 988 & ,384 & 6,620 & 1 & ,010 \\
\hline & [gorevNom=6,00] &,- 916 &, 383 & 5,734 & 1 &, 017 \\
\hline & [gorevNom=7,00] & $0 \mathrm{a}$ & & & 0 & \\
\hline
\end{tabular}


Model 2 seyahat acentaları çalışanlarının işletmelerine bağlılıklarını (işletmede uzun yıllar çalışma konusundaki tutumlarını) sınamaktadır. İlgili bağımlı değişkeni açıklayan 5 ÇYK değişkeni ile iki demografik faktör tespit edilmiştir. İşletmeye bağl1lığı etkileyen konular "yöneticilerin adil olması", "bölümde işle ilgili toplantıların verimli geçmesi", bölümünün zaman ve maliyet açısından verimli çalışması", "işletmeye yüksek katkı sağlamak için çalışma" ve “aldığ 1 ücretten tatmin olmak”tır. Bu değişkenlerden her birinde bir birimlik artış işletmeye bağlılığı değişik düzeylerde artırmaktadır. Bu anlamda en yüksek etki derecesi ücret tatminin etkisidir. Aldığ artarsa bunun işletmeye bağlılığa etkisi 0,59 birim olacaktır. Demirer vd. (2010) seyahat acentalarının satış personeli üzerine yaptığı çalışmada işletmeye bağlılı̆̆ en yüksek düzeyde etkileyen unsurun denetçiye yönelik algılanan sorumluluk düzeyi olarak tespit etmiştir. Bu çalışmada da yöneticilerin işlerini yapmaları ile ilgili algılamanın etkili olduğunun bulunması Demirer vd. (2010)'u teyid eder niteliktedir denebilir. Bunun yanında 1-2 yıldır işletmede çalışıyor olmak işletmeye bağl1lı̆̆ negatif yönde etkilemektedir. Ancak, bölüm yöneticisi, Şef ve supervisor olarak görev yapmak işletmeye bağlllı̆g 1 pozitif yönde etkileyen bir durumdur (Tablo 9).

Tablo 9. "Çalıştı̆ıım işletmede uzun yıllar çalı̧̧abilirim" İfadesini Açıklayan Değişkenler ve Parametre Tahminleri (Model 2)

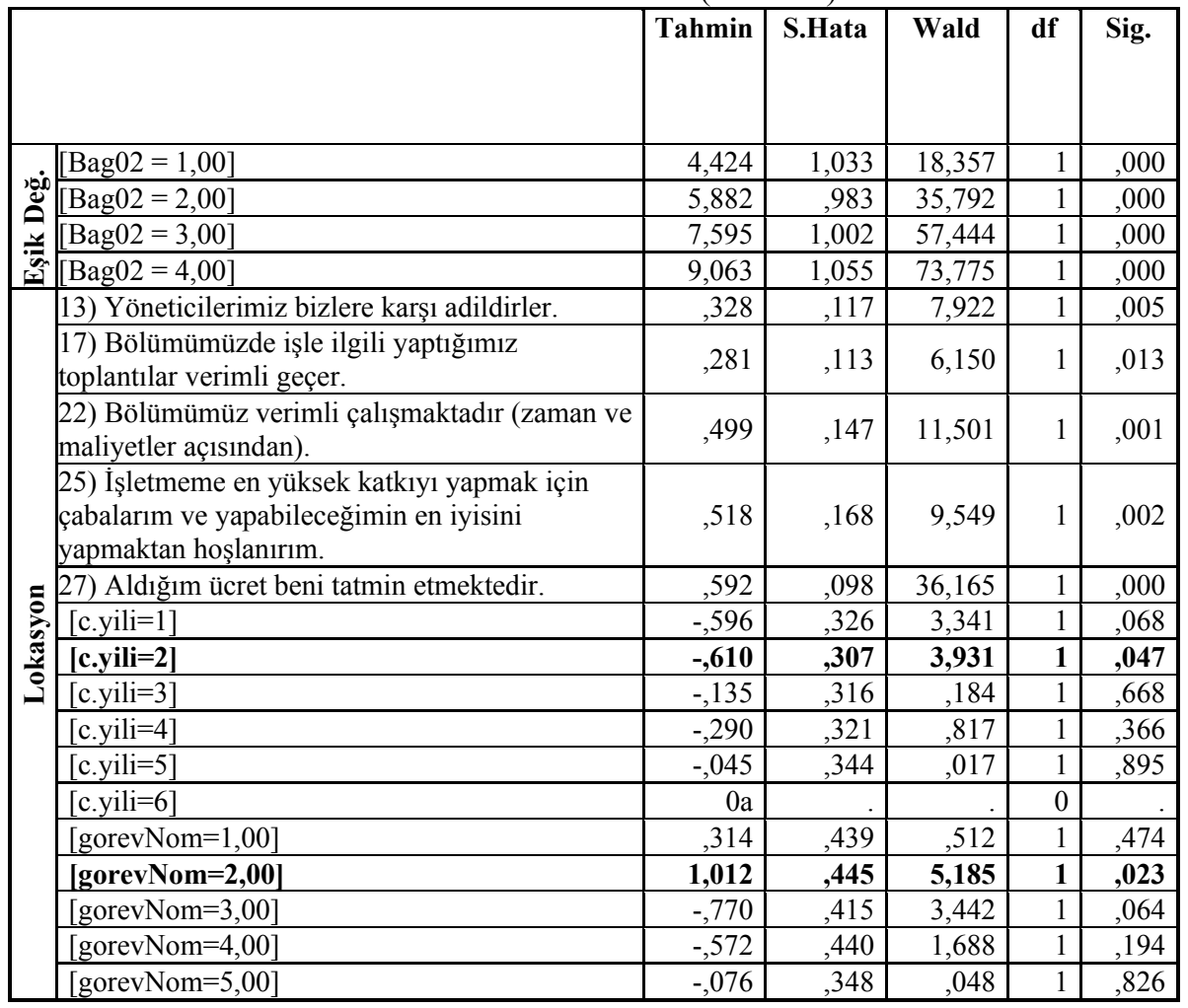


Yönetim ve Ekonomi 22/1 (2015) 239-256

\begin{tabular}{|l|l|r|r|r|r|r|}
\hline & {$[$ gorevNom $=6,00]$} &,- 022 &, 338 &, 004 & 1 &, 948 \\
\hline & gorevNom $=7,00]$ & $0^{\mathrm{a}}$ &. &. & 0 &. \\
\hline
\end{tabular}

İş koluna bağlılık konusunda Model 3'ün sınanmas1 neticesinde etkili olan üç değişken ve bir de demografik faktör tespit edilmiştir. Değişkenler; "İşim benim için ilgi çekici bir iştir", "yaptığım iş işletmenin başarısı için önemlidir" ve "İ̧sletmeme en yüksek katkıyı yapmak için çabalarım ve yapabileceğimin en iyisini yapmaktan hoşlanırım" değişkenleridir. Bu değişkenlerden en önemli etki üreten sonuncu değişkendir. İşletmeye yüksek katkı yapmaya çaba konusundaki tutum bir birim artırılırsa iş koluna bağl1lık 0,58 birimlik bir artışa uğrayacaktır. Diğer yandan, acenta sahibi ve müdürü olmak ve bölüm yöneticisi, şef, süpervisor görevlerinde bulunmak iş koluna bağl1lık üreten unsurlardır (Tablo 10).

Tablo 10. "Seyahat Acentacılığı Alanında Uzun Yıllar Çalışabilirim" İfadesini Açıklayan Değişkenler ve Parametre Tahminleri (Model 3)

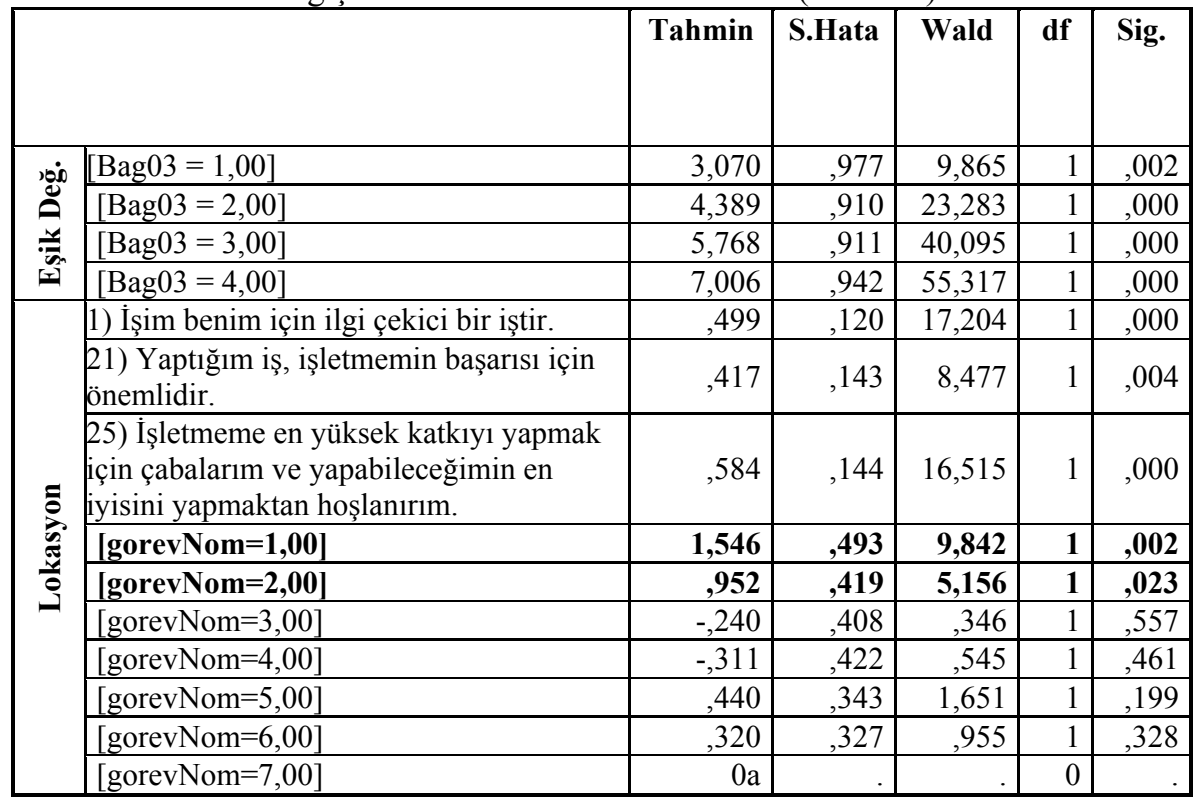

\section{DEĞERLENDİRME VE SONUÇ}

Üç model kapsamında da etki ortaya koyan ortak değişken "işletmeye en yüksek katkıyı yapmak için çaba göstermek"le ilgili olandır. Bu durum çalışanın işinden memnun olmasına, işletmesine ve iş koluna bağlılığı aynı anda açıklama gücüne sahip olan unsurun içsel bir çaba olduğunu ve bu çabanın işletmeye sağlayabileceği en yüksek katkıyı sağlamak adına ortaya koyulduğunu göstermektedir. Yine iş memnuniyeti konusunda işin kendisi için bir şans olduğu düşüncesi çalışanın motivasyonu ile ilgili bir konudur. $\mathrm{Bu}$ içsel etkenleri işletmenin yüksek kapasiteli çalışması algısı ve yöneticilerin tutumu gibi çalışma yaşamının algılanmasını belirleyen temel bazı faktörler izlemektedir. İşletmeye bağlılık konusu da paralel bazı değişkenlerce açıklanmaktadır. Yöneticilerin adaleti, toplantıların verimli geçmesi ve işletmenin verimli çalışması konuları çalışma ortamının temel konularıdır. İşinden memnun olma ve işletmeye bağlılığ1 
açıklamak açısından, alınan ücretin kişiyi tatmin edip etmemesi de önemli rol oynamaktadır. Aldığ 1 ücretten tatmin olma düzeyinin iş alanına bağlılı̆g 1 etkilemiyor olması ilginç bir sonuçtur. Bu durum seyahat acentası çalışanlarının çalışma alanlarına yaklaşımlarının kazanç düzeyi konusundaki algılamalarıyla ilgili olmadığını ortaya koymaktadır. İş alanına bağlılığın işi ilgi çekici bulma, işini işletmesi için değerli bulma ve işletmeye katkı sağlamaya çabalama konularınca belirlendiği anlaşılmaktadır. Bu durumda işinin önemi konusundaki algılaması iş alanına bağl1lı̆̆ 1 belirliyor denebilir. Görev konusunda üst düzey yönetim ekiplerinin daha yüksek oranda işletme ve iş alanına bağlılı̆̆ 1 söz konusudur.

Seyahat acentası çalışanlarının çalışma yaşamı kalitesi boyutlarına ilişkin değerlendirmeleri olumlu görünmektedir. $\mathrm{Bu}$ boyutlardan iş memnuniyeti, işletmeye ve iş alanına bağlılığı belirleyen az sayıda etken tespit edilmiştir. Bunlar; aldığ 1 ücretten tatmin olma gibi tamamen maddi beklenti yanında işletmeye en yüksek katkıyı sunma, işin kendisi için şans olduğunu düşünme, işin ilginç olduğunu düşünme, işin işletme için önemli olduğunu düşünme gibi içsel (duygusal da denebilir) etkenler ve yöneticilerin adil davranması, süreçlerin verimliliği gibi çalışma ortamını belirleyen uygulamaya dönük etkenlerdir. $\mathrm{Bu}$ açıdan bakınca seyahat acentası yöneticilerine yönelik olarak çalışma yaşamı kalitesinin etki çerçevesini düşündüklerinde ilgili boyutlarda geliştirme çalışmalarına gitmeleri önerilebilir. Başta, fedakarca çalışmayı kanıksamış çalışanları işe almaya odaklanmak, sonrasında çalışanlarının işlerini önemli görmeleri için bilgilendirilmeleri, yöneticileri ile adil ilişkiler geliştirebilmeleri, tüm işletme süreçleri içinde verimliliği baz alan düzenlemelere gitmeleri gereklidir. Çalışma yaşamı kalitesini belirleyen değişkenlerin iş memnuniyeti, işletmeye ve iş alanına bağlılığı etkilemeleri konusunda az sayıda değişkenin belirleyici çıkması; çalışanların iş arkadaşları ile ilgili tutumları, yöneticilerle iletişimleri, işyerinin fiziksel koşulları, farklı çalışanların arasındaki uyum, sahip olunan bilgi ve beceri düzeyi, stres düzeyi ve üretimin toplumsal faydası gibi konuların etki ortaya koymuyor görünmesi nedenleri ile birlikte sorgulanmalıdır. Yine yaş, cinsiyet, eğitim düzeyi, şehir gibi demografik etkenlerin de bir belirleyiciliğinin olmamasının sektörel nedenlerini belirlemek üzere çalışmalar yapilabilir.

\section{KAYNAKLAR}

AĞAÇ S., GÜRŞAHBAZ, N., ÖZELMAS KAHYA, S. ve ARGA ŞAHİNOĞLU, M. (2010), "Hazır Giyim İşletmelerindeki İşgörenlerin İş Doyum Durumlarının Belirlenmesine Yönelik Bir Araştırma”, e-Journal of New World Sciences Academy, 5 (2), 50-65.

AKIN, B. ve ŞENTÜRK, E. (2012), "Bireylerin Mutluluk Düzeylerinin Ordinal Lojistik Regresyon Analizi İle İncelenmesi”, Öneri, 10(37), 183-193.

ALTAY, H. ve AKGÜL, V. (2010), "Seyahat Acentaları Çalışanlarının Tükenmişlik Düzeyi: Hatay Örneği”, Mustafa Kemal Üniversitesi Sosyal Bilimler Enstitüsü Dergisi, 7(14), 87-112.

CACIOPPE, R. ve MOCK, P. (1984), "A comparison of the quality of work experience in government and private organizations", Human Relations, 37(11), 923-940. 
CHAN, S.C.H. (2010), "Does workplace fun matter? Developing a useable typology of workplace fun in a qualitative study" International Journal of Hospitality Management, 29(4), 720728.

CLUGSTON, M. (2000), "The Mediating Effects of Multidimensional Commitment on Job Satisfaction and Intend to Leave", Journal of Organizational Behavior, 21(4), 477- 486.

DAVRAS, Ö. ve GÜLMEZ, M. (2013), "Otel İşletmelerinde Çalışan Memnuniyetine Etki Eden Faktörler: Kemer-Lara-Belek-Side-Alanya Bölgelerinde Bir Çalışma”, Anatolia: Turizm Araştırmaları Dergisi, 24 (2), 167-184.

DEMIR, M. ve TÜTÜNCÜ, Ö. (2010), “Ağırlama İşletmelerinde Örgütsel Sapma ile İşten Ayrılma Eğilimi Arasındaki İlişki”, Anatolia: Turizm Araştırmaları Dergisi, 21(1), 64-74.

DEMIRER, H., GÜREŞ, N. ve AKGÜL, V. (2010), "Organizational Commitment And Job Satisfaction: The Influence Of Individual And Organizational Factors On Sales Persons' Work Attitudes In Travel Agencies”, Mustafa Kemal Üniversitesi Sosyal Bilimler Enstitüsü Dergisi, 7(14), 41-62.

DOLBIER, C. L., WEBSTER, J. A., MCCALISTER, K. T., MALLON, M.W. ve STEINHARDT, M. A. (2005), "Reliability and Validity of a Single-Item Measure of Job Satisfaction", American Journal Health Promotion, http://www.edb.utexas.edu/steinhardt/Files/Dolbier.McCalister.Steinhardt(2005).pdf (03/04/2014).

GILlET, N., FOUQUEREAUA, E., BONNAUD-ANTIGNAC, A., MOKOUNKOLOA, R. ve COLOMBAT, P. (2013), "The mediating role of organizational justice in the relationship between transformational leadership and nurses' quality of work life: A cross-sectional questionnaire survey", International Journal of Nursing Studies, 50(10), 1359-1367.

GRAHAM, M.W. ve MESSNER, P.E.(1998), "Principals and Job Satisfactions", International Journal of Educational Management, 12(5), 196-202.

GÜNLÜ, E., AKSARAYLI, M. ve ŞAHIN PERÇİN, N. (2010), "Job Satisfaction and Organizational Commitment of Hotel Managers in Turkey", International Journal of Contemporary Hospitality Management, 22(5), 693-717.

HAİR, J. F., BLACK, W. C., BABİN, B. J., ANDERSON, R. E. ve TATHAM, R. L. (2006), Multivariate Data Analysis, 6. Bask1, New Jersey: Prentice Hall

HOX, J.J. (2010), Multilevel Analysis, Techniques and Applications, 2. Bask1, Routhledge.

IBM (2011), "Ordinal Regression", http://pic.dhe.ibm.com/infocenter/spssstat/v20r0m0/index.jsp?topic=\%2Fcom.ibm.spss.sta tistics.help\%2Fidh plum.htm, (27/12/2013).

KANTEN, S. ve SADULLAH, Ö. (2012), "An empirical research on relationship quality of work life and work engagement", Procedia - Social and Behavioral Sciences, 62, 360 - 366.

KARA, D., UYSAL, M., SIRGY, M.J. ve LEE, G. (2013), "The effects of leadership style on employee well-being in hospitality", International Journal of Hospitality Management, 34, 9-18.

KOONMEE, K., SINGHAPAKDI, A., VIRAKUL, B., ve LEE, D. (2010), "Ethics institutionalization, quality of work life, and employee job-related outcomes: A survey of human resource managers in Thailand", Journal of Business Research, 63, 20-26.

MARTA, J.K.M., SINGHAPAKDI, A., LEE, D., SIRGY, M.J., KOONMEE, K. ve VIRAKUL, B. (2013), "Perceptions about ethics institutionalization and quality of work life: Thai versus American marketing managers", Journal of Business Research, 66, 381-389.

NAGY, S. M. (2002), "Using a single-item approach to measure facet job satisfaction", Journal of Occupational and Organizational Psychology, 75, 77-86.

NAUDE, M.R., KRUGER, S. ve SAAYMAN, M. (2013), "Who to work for: A South African hotel or resort?", International Journal of Hospitality Management, 33, 331-338.

SGK (2014), “Aylı İstatistik Bültenleri”, http://www.sgk.gov.tr/wps/portal/tr/kurumsal/istatistikler, $(12 / 05 / 2014)$.

SINGHAPAKDI, A., SIRGY, M.J. ve LEE, D. (2010, "Is small business better than big business for marketing managers?", Journal of Business Research, 63, 418-423. 
SINGHAPAKDI, A., SIRGY, M.J., LEE, D., SENASU, K., YU, G.B. ve NISISU, A.M. (2014), "Gender disparity in job satisfaction of Western versus Asian managers", Journal of Business Research, 67(6), 1257-1266.

SIRGY, M.J., EFRATY, D., SIEGEL, P. ve LEE, D. (2001), “A New Measure of Quality of Work Life (QWL) Based on Need Satisfaction And Spillover Theories", Social Indicators Research, 55, 241-302.

ŞERBETÇİ, A. ve ÖZÇOMAK, M.S. (2013), "Sıralı Lojistik Regresyon Analizi İle İstatistik Ve Ekonometri, Derslerinde Başarıyı Etkileyen Faktörlerin Belirlenmesi: Atatürk Üniversitesi İktisadi ve İdari Bilimler Fakültesi Öğrencileri Üzerine Bir Uygulama”, Kahramanmaraş Sütçü İmam Üniversitesi İktisadi Ve İdari Bilimler Fakültesi Dergisi, 3(1), 89-110.

TURSAB (2014), "Seyahat Acentaları", http://www.tursab.org.tr/tr/seyahat-acentalari/seyahatacentasi-arama?search $=1,(12 / 05 / 2014)$.

TÜTÜNCÜ, Ö. ve DEMIR, M. (2002), Konaklama Isşletmelerinde İnsan Kaynakları Yönetimi ve İsgücü Hareketlerinin Analizi, Ankara: Turhan Kitabevi.

WANOUS, J. P., REICHERS, A. E., ve HUDY, M. J. (1997), "Overall job satisfaction: How good are single-item measures?", Journal of Applied Psychology, 82, 247-252.

WANOUS, J.P. ve HUDY, M.J. (2001), "Single-Item Reliability: A Replication and Extension", Organizational Research Methods, 4(4), 361-375.

YÜKSEL, İ. (2004), "Çalışma Yaşamı Kalitesinin Tipik ve Atipik İstihdam Açısından İncelenmesi”, Doğuş Üniversitesi Dergisi, 5(1), 47-58. 